DOI: 10.12731/wsd-2018-2-74-92

УДК 612.111-026.13: 599.323.45-117

\title{
РЕАКТИВНОСТЬ ЭРИТРОЦИТОВ КРЫС В УСЛОВИЯХ ФИЗИЧЕСКОЙ НАГРУЗКИ РАЗНОЙ ИНТЕНСИВНОСТИ
}

Монгалёв Н.П., Рубцова Л.Ю., Шадрина В.Д., Черных А.А., Вахнина Н.А., Макарова И.А., Романова А.М., Алисултанова Н.Ж., Василенко Т.Ф., Бойко Е.P.

Цель. Изучить морфофункииональное состояние красной крови крыс в зависимости от физической нагрузки «до отказа».

Материалы и методы. В исследовании использовали практически здоровых половозрельх крыс-самцов Wistar: контроль, нахождение в воде без движения, свободное плавание и плавание с грузом 2\%, 6\%, 8\%, 10\% и 15\% от массы тела «до отказа» согласно протоколу по биоэтике утвержденному ИФ Коми НЦ УрО РАН. В крови определяли уровень гемоглобина, гематокрита, количество эритроцчитов и ретикулоцчитов. Измеряли диаметр 100 эритроцитов окрашенных по Романовскому-Гимза и бриллиантовым крезиловым синим. Статистическую значимость различий реакичий исследованных животных оченивали с помощьью непараметрического критерия Крускала-Уоллиса.

Результаты. Физическая нагрузка «до отказа» характеризовалась повышением величины гематокрита, гемоглобина, количеством эритроциитов в крови крыс и физиологическим ретикулоцитоозом, наряду со снижением конценттрации гемоглобина в эритроците. Отмечено, что распределение ретикулоцитов по диаметру в пределах 6.4-6.7 мкм у плавающих крыс с грузом 8\% от массы тела соответствует кривой Прайс-Джсонса интактных животных.

Заключение. У крыс в зависимости от характера и интенсивности физической нагрузки проявились разнонаправленные сдвиги в клеточном составе красной крови. Практическое использование только тестового плавания крыс с грузом $8 \%$ от массы тела, судя по реакичи эритроцитов, является физиологически обоснованныл.

Ключевые слова: крысы; эритроцитыь; ретикулоцитыь; диаметр; физическая нагрузка «до отказа». 


\title{
REACTIVITY OF RAT ERYTHROCYTES UNDER CONDITIONS OF PHYSICAL STRESS OF DIFFERENT INTENSITY
}

\author{
Mongalev N.P., Rubtsova L.Yu., Shadrina V. D., Chernykh A.A., \\ Vahnina N.A., Makarova I.A., Romanova A.M., Alisultanova N.Zh., \\ Vasilenko T.F., Bojko E.R.
}

Background. To study the morphofunctional state of red blood in rats depending on the physical load "to failure".

Materials and methods. The study used practically healthy adult male rats of the Wistar: control, staying in water without movement, free swimming and swimming with a load of $2 \%, 6 \%, 8 \%, 10 \%$ and $15 \%$ of body weight "to failure" according to the protocol on bioethics approved by the IPhys Komi SC $U B$ RAS. In the blood, the level of hemoglobin, hematocrit, the number of erythrocytes and reticulocytes was determined. The diameter of 100 erythrocytes stained according to Romanovsky-Giemsa and diamond cresyl blue was measured. The statistical significance of the differences was assessed using the nonparametric Kruskal-Wallis criterion.

Results. The physical load "to failure» was characterized by an increase in hematocrit, hemoglobin, and the number of erythrocytes in the blood of rats and physiological reticulocytosis, along with a decrease in the concentration of hemoglobin in the erythrocyte. It was noted that the distribution of reticulocytes of diameters within 6.4-6.7 $\mu \mathrm{m}$ in floating rats with a weight of 8\% of body weight corresponds to the Price-Jones curve of intact animals.

Conclusion. In rats, depending on the intensity of exercise, multidirectional shifts in the cellular composition of red blood appeared. Practical use only of the test swimming of rats with a weight of $8 \%$ of body weight, judging by the nature of the reaction of erythrocytes, is physiologically justified.

Keywords: rats; erythrocytes; reticulocytes; diameter; physical load "to failure".

\section{Введение}

Раскрытие механизмов реализации потенциальных возможностей организма в условиях физических нагрузок является одним из ключевых вопросов физиологии. Функциональное состояние организма в условиях двигательной активности зависит от эффективности системы транспор- 
та кислорода, составная часть которого - периферическое звено эритрона. Особое значение в адаптивных реакциях организма к физическим нагрузкам принадлежит молодым эритроцитам, увеличение количества которых влияет на величину среднего диаметра эритроцитов и выполнение экстренного восполнения дефицита кислорода [1, 2]. Исследование реакции красной крови на физическую нагрузку предполагает поэтапное включение различных механизмов, обеспечивающих кислородный запрос организма $[3,4,5,6,7]$ и проявление способности противостоять механическому, окислительному и осмотическому стрессу in vivo [8]. Реакция организма к физическим нагрузкам сопровождается перераспределением резервов функциональных систем, реагирующих на экстремальную ситуацию $[9,10]$. В целом мышечная нагрузка существенно влияет на морфологическую модификацию эритрона [11] и характеризуется увеличением числа эритроцитов, содержанием гемоглобина в крови [12], снижением средней концентрации гемоглобина в эритроците [13]. Перераспределение клеток крови при этом может быть типичным [14], поскольку изначально реакция организма на молекулярном и клеточном уровне при действии внешних и внутренних факторов среды у животных и человека однотипна [15].

\section{Цель исследования}

На основе изучения морфофункционального состояния красной крови крыс определить оптимальный уровень физической нагрузки и физиологической реакции эритроцитов в тестовых условиях плавания «до отказа».

\section{Материал и методы}

Для исследования влияния физической нагрузки на морфофункциональное состояние крови использовали половозрелых крыс-самцов Wistar (масса тела 250-300 г). Крыс содержали по 4 особи в клетке, на стандартном рационе вивария, доступом к воде ab libitum, при температуре $21 \pm 1^{\circ} \mathrm{C}$ и 12 -часовом освещении. Протокол эксперимента утвержден локальным комитетом по биоэтике при ИФ Коми НЦ УрО РАН. Животные были разделены на семь групп. Первая группа животных - интактные, контроль $(\mathrm{n}=8)$, вторая группа находилась сидя в воде без движения (ВБД) в небольшом количестве воды высотой до 7 см в течение 60 минут $(\mathrm{n}=6)$, третья группа вынужденно плавала в течение 60 минут без груза $(\mathrm{n}=7)$. Животные 4-8 групп участвовали в плавании «до отказа» с гру- 
зом $2 \%(\mathrm{n}=6), 6 \%(\mathrm{n}=5), 8 \%(\mathrm{n}=8), 10 \%(\mathrm{n}=6)$ и $15 \%(\mathrm{n}=6)$ от массы тела. Экспериментальные животные, за исключением первой и второй групп предварительно проходили адаптацию к воде [16] с последующим восстановлением в течение 14 дней.

Кровь животных, взятой после наркоза с последующей декапитацией, стабилизировали гепарином (5000 ед./мл, АКОС, Россия). Определяли уровень гемоглобина по Сали ГС-3, концентрацию гемоглобина в эритроците расчетным способом, показатель гематокрита с использованием центрифуги MPW-310 (“Mechanika Precyzyina” Poland), количество эритроцитов в камере Горяева и ретикулоцитов на мазках после инкубирования крови в течение 12-15 мин с 1\% раствором бриллиантового крезилового синего (Диахим-Гемистейн-РЕЦ, Россия). Измеряли диаметр 100 эритроцитов окрашенных по Романовскому-Гимза (Vital-Development, Россия) и ретикулоцитов с помощью микроскопа PZO (Poland) с масляной иммерсией, увеличение об. $100^{\mathrm{x}}$ ок. с градуированной шкалой $12^{\mathrm{x}}$ [17].

Результаты обрабатывали статистически с использованием однофакторного дисперсионного анализа с помощью робустной функции tr1way пакета WRS2 статистической программы R (версия 3.4.2). Статистическую значимость различий реакций исследованных животных оценивали на основании непараметрического критерия Крускала-Уоллиса. Различия считались значимыми при $\mathrm{p}<0.05$. Определяли коэффициент ранговой корреляции Спирмена [18].

\section{Результаты и их обсуждение}

Уровень гемоглобина и других параметров красной крови интактных животных соответствуют известным величинам характерным для крыс (табл.) $[19,20,21]$.

Таблицча.

Сравнительная характеристика показателей красной крови животных в покое и в условии физической нагрузки разной интенсивности $(\mathrm{M} \pm \mathrm{m})$

\begin{tabular}{|c|c|c|c|c|c|c|c|c|}
\hline \multirow{3}{*}{$\begin{array}{c}\text { Группа } \\
\text { животных }\end{array}$} & Первая & Вторая & Третья & $\begin{array}{c}\text { Четвер- } \\
\text { тая }\end{array}$ & Пятая & Шестая & Седьмая & Восьмая \\
\hline & Кон- & ВБД - & Плава- & \multicolumn{5}{|c|}{$\begin{array}{c}\text { Плавание в тесте «до отказа»: } \\
\text { \% от массы тела/мин }\end{array}$} \\
\hline & & & & $2 / 82.0$ & $6 / 9.4$ & $8 / 3.1$ & $10 / 2.0$ & $15 / 1.4$ \\
\hline Гематокрит, \% & $\begin{array}{c}44.97 \pm \\
0.40\end{array}$ & $\begin{array}{c}43.36 \pm \\
0.60\end{array}$ & $\begin{array}{c}44.98 \pm \\
0.59\end{array}$ & $\begin{array}{c}48.80 \pm \\
1.57 \\
* * *\end{array}$ & $\begin{array}{c}50.90 \pm \\
1.23 \\
* * *\end{array}$ & $\begin{array}{c}52.07 \pm \\
0.68 \\
* * *\end{array}$ & $\begin{array}{c}50.07 \pm \\
0.89 \\
* * *\end{array}$ & $\begin{array}{c}49.04 \pm \\
1.48 \\
* *\end{array}$ \\
\hline
\end{tabular}


Siberian Journal of Life Sciences and Agriculture, Vol 10, №2, 2018

\begin{tabular}{|c|c|c|c|c|c|c|c|c|}
\hline \multicolumn{9}{|c|}{ Окончание табл. } \\
\hline Гемоглобин, г/л & $\begin{array}{c}144.89 \pm \\
1.22\end{array}$ & $\begin{array}{c}139.11 \pm \\
2.42\end{array}$ & $\begin{array}{c}144.67 \pm \\
2.57\end{array}$ & $\begin{array}{c}150.02 \pm \\
3.50\end{array}$ & $\begin{array}{c}152.24 \pm \\
2.56^{*}\end{array}$ & $\begin{array}{c}151.43 \pm \\
2.20\end{array}$ & $\begin{array}{c}151.52 \pm \\
2.00\end{array}$ & $\begin{array}{c}152.30 \pm \\
3.15\end{array}$ \\
\hline $\begin{array}{l}\text { Концентрация ге- } \\
\text { моглобина в эритро- } \\
\text { ците, \% }\end{array}$ & $\begin{array}{c}32.23 \pm \\
0.35\end{array}$ & $\begin{array}{c}31.99 \pm \\
0.36\end{array}$ & $\begin{array}{c}31.48 \pm \\
0.46\end{array}$ & $\begin{array}{l}30.18 \pm \\
0.51 * *\end{array}$ & $\begin{array}{l}28.97 \pm \\
0.39 * *\end{array}$ & $\begin{array}{c}29.27 \pm \\
0.29 * * *\end{array}$ & $\begin{array}{l}30.28 \pm \\
0.39 * *\end{array}$ & $\begin{array}{c}31.12 \pm \\
0.71\end{array}$ \\
\hline Эритроциты, 10²/л & $\begin{array}{c}8.17 \pm \\
0.15\end{array}$ & $\begin{array}{c}7.32 \pm \\
0.20\end{array}$ & $\begin{array}{c}8.32 \pm \\
0.30\end{array}$ & $\begin{array}{c}8.09 \pm \\
0.28\end{array}$ & $\begin{array}{l}8.82 \pm \\
0.18^{*}\end{array}$ & $\begin{array}{l}9.27 \pm \\
0.19^{*}\end{array}$ & $\begin{array}{l}9.06 \pm \\
0.19 *\end{array}$ & $\begin{array}{l}8.80 \pm \\
0.39 *\end{array}$ \\
\hline $\begin{array}{l}\text { Диаметр эритроцитов, } \\
\text { мкм }\end{array}$ & $\begin{array}{c}6.17 \pm \\
0.03\end{array}$ & $\begin{array}{l}5.97 \pm \\
0.04 *\end{array}$ & $\begin{array}{c}6.11 \pm \\
0.07\end{array}$ & $\begin{array}{c}6.13 \pm \\
0.04\end{array}$ & $\begin{array}{c}6.35 \pm \\
0.06\end{array}$ & $\begin{array}{c}6.18 \pm \\
0.05\end{array}$ & $\begin{array}{c}6.07 \pm \\
0.05\end{array}$ & $\begin{array}{c}6.06 \pm \\
0.04\end{array}$ \\
\hline $\begin{array}{l}\text { Ретикулоциты, } \\
10^{12} / л\end{array}$ & $\begin{array}{c}0.094 \pm \\
0.003\end{array}$ & $\begin{array}{c}0.141 \pm \\
0.014\end{array}$ & $\begin{array}{c}0.196 \pm \\
0.013 \\
* *\end{array}$ & $\begin{array}{c}0.165 \pm \\
0.010 \\
*\end{array}$ & $\begin{array}{c}0.190 \pm \\
0.020 \\
* * *\end{array}$ & $\begin{array}{l}0.220 \pm \\
0.023 \\
* * *\end{array}$ & $\begin{array}{l}0.220 \pm \\
0.010 \\
* * *\end{array}$ & $\begin{array}{c}0.210 \pm \\
0.020 \\
* * *\end{array}$ \\
\hline $\begin{array}{l}\text { Диаметр ретикулоци- } \\
\text { тов, мкм }\end{array}$ & $\begin{array}{c}6.39 \pm \\
0.04\end{array}$ & $\begin{array}{l}5.90 \pm \\
0.08^{*}\end{array}$ & $\begin{array}{c}5.93 \pm \\
0.07\end{array}$ & $\begin{array}{c}6.39 \pm \\
0.07\end{array}$ & $\begin{array}{c}6.53 \pm \\
0.09\end{array}$ & $\begin{array}{c}6.58 \pm \\
0.06\end{array}$ & $\begin{array}{c}6.33 \pm \\
0.07\end{array}$ & $\begin{array}{c}6.11 \pm \\
0.08\end{array}$ \\
\hline ДЭОБКС, мкм & $\begin{array}{c}5.94 \pm \\
0.04\end{array}$ & $\begin{array}{c}5.66 \pm \\
0.06 * *\end{array}$ & $\begin{array}{c}5.70 \pm \\
0.07 * *\end{array}$ & $\begin{array}{c}5.98 \pm \\
0.03\end{array}$ & $\begin{array}{c}6.07 \pm \\
0.09\end{array}$ & $\begin{array}{c}5.98 \pm \\
0.04\end{array}$ & $\begin{array}{c}5.90 \pm \\
0.03\end{array}$ & $\begin{array}{l}5.74 \pm \\
0.07 *\end{array}$ \\
\hline
\end{tabular}

Примечания: статистически значимые отличия показателей: $*$ - $<<0.05$, ** _ $\mathrm{p}<0.01, * * *-\mathrm{p}<0.001$ по отношению к животным первой группы. ДЭОБКС диаметр эритроцитов после окрашивания бриллиантовым крезиловым синим.

Морфологически эритроциты выглядели как нормохромные со слабо выраженной полихромазией в отдельных клетках до 0.1-1\%. Ретикулоцитарная субстанция в цитоплазме проявлялась в виде зернистости часто неправильной формы, иногда с тонкой нитчатостью.

Средний диаметр молодых эритроцитов у крыс разных групп коле-

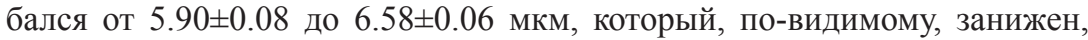
поскольку средний диаметр зрелых эритроцитов после окрашивания in vitro бриллиантовым крезиловым синим уменьшался. Это может свидетельствовать об абсолютно большей величине диаметра ретикулоцитов (табл.), что необходимо учитывать при анализе распределения эритроцитов по диаметру. Величина физической нагрузки у крыс не выявила различий в динамике изменения среднего диаметра молодых и зрелых эритроцитов (табл.) $(\mathrm{r}=0.994 ; \mathrm{p}=0.0001)$.

Установлено, что животные опытных групп различались по исследуемым параметрам красной крови от крыс контрольной группы. У крыс третьей группы по сравнению с животными первой группы выше абсолютное количество ретикулоцитов $(\mathrm{p}=0.0041)$, что свидетельствует о более активном выходе эритроидных клеток из костного мозга в периферическую кровь в условиях плавания (табл.). Наметившийся тренд к увеличению количества ретикулоцитов у животных второй группы 
$(\mathrm{p}=0.0541)$ сопровождался повышением концентрации ретикулоцитов меньшего диаметра, о чем свидетельствует сдвиг кривой Прайс-Джонса влево (таблица, рис. 1).

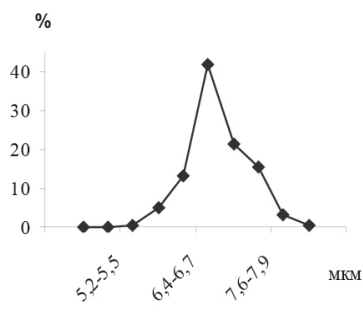

первая группа (контроль)

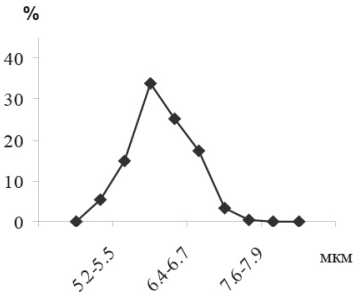

вторая группа

(ВБД)

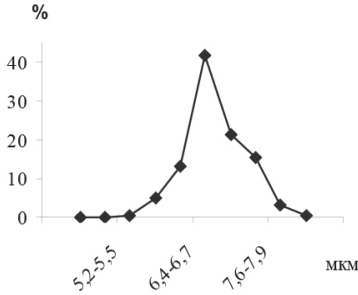

шестая группа (плавание, 8\%)

Рис. 1. Распределение ретикулоцитов по диаметру из смешанной крови крыс (кривые Прайс-Джонса) в условиях физической нагрузки разной интенсивности

Содержание ретикулоцитов в крови животных с диаметром 6.4-6.7 мкм составляет основное звено молодых эритроцитов. Количество ретикулоцитов в этом диапазоне у крыс первой группы составило $41.8 \pm 1.7 \%$, второй группы $-17.5 \pm 3.6 \%$ и в третьей группе $-14.1 \pm 1.8 \%$. В условиях плавания животных «до отказа» этот показатель увеличился (у крыс шестой группы до $41.9 \pm 2.5 \%$ ) и соответствовал распределению кривой Прайс-Джонса характерному для интактных животных (рис. 1). Уменьшение среднего диаметра ретикулоцитов, соответствующее смещению кривой Прайс-Джонса влево, дает основание предполагать о наличии состояния стресса у крыс второй группы, которое нивелируется в условиях физической нагрузки. Возможно, в отличие от стресса, мышечная активность может быть функционально более значимым фактором для организма, влияющим на распределение эритроцитов в крови животных.

Характер распределения эритроцитов по диаметру является одним из признаков, отражающих состояние гомеостазиса транспортной системы крови [3]. Обращает внимание постоянство одновершинной формы кривой Прайс-Джонса у крыс в условиях физической нагрузки разной интенсивности. Можно полагать, что наблюдаемые сдвиги кривой обусловленные элиминацией менее стойких клеток (у крыс второй группы, вероятно, преимущественно более крупных по диаметру) и, напротив, «сохранение» более крупных клеток у животных шестой группы в условиях мышечной активности. 
Известно, что элиминация менее стойких клеток может происходить вне и внутри сосудов периферической крови [22]. У людей примерно $0.5 \%$ эритроцитов находятся в состоянии гемолиза [23], однако эта величина может увеличиваться в зависимости от изменений условий окружающей среды эритроцита до $10 \%$ и более $[24,25]$. Не разрушенные эритроциты (например, ретикулоциты), вероятно, обладают повышенной резистентностью к гипо- и гипергидратации плазмы $[26,27]$.

Обсуждается вопрос о возможности влияния уровня лактата в крови на характер распределения кривой Прайс-Джонса. Возможно, у крыс шестой группы нормальное распределение ретикулоцитов по диаметру (близкое к распределению в первой группе) является следствием достижения порога анаэробного обмена, что согласуется с данными A.F. Brito et al. [16], М.С. Зайцевой и др. [28] и соответствует нагрузке плавания с 6-8\% грузом от массы тела, то есть условиям лактоцидоза. Аналогичную зависимость возвращения к исходному распределению зрелых эритроцитов по диаметру ко времени достижения порога анаэробного обмена отмечали у лыжников-гонщиков в условиях физической нагрузки на велоэргометре [29].

Количественный показатель эритроцитов во многом обусловливает величину гематокрита, который был выше у животных четвертой-восьмой групп по сравнению с крысами контрольной группы (от $\mathrm{p}=0.00015$ до $\mathrm{p}=0.00246$ ) (табл., рис. 2). В то же время высокий показатель гематокрита может быть связан с выходом эритроцитов в кровь из депо вследствие действия мышечной нагрузки [30] и переходом части воды в интерстициальную область [31]. Возможно, в условиях плавательной нагрузки повышается гидратированность эритроцитов, что характерно для крыс четвертой - седьмой групп, поскольку в этих эритроцитах уменьшилась концентрация гемоглобина.

Нами отмечена обратная связь изменения концентрации гемоглобина в эритроците от показателя гематокрита крови в зависимости от уровня физической нагрузки (табл., рис. 2) (r= - 0.952; $\mathrm{p}=0.0001)$.

Известно, что процесс «разбавления» гемоглобина in vitro связан с регуляцией кислородного запроса тканей, поскольку затрагивает кислородозависимый транспорт ионов в эритроцитах $[32,33]$. Поэтому уменьшение концентрации гемоглобина в эритроидной клетке, вероятно, можно отнести к явлению срочной адаптации крыс в условиях физической нагрузки, поскольку набухание эритроцитов, сопровождающееся повышением сродства гемоглобина к кислороду, способствует процессу оксигенации в легких, а наличие ДФГ-дезоксигенации в капиллярах мышечной ткани [15]. 


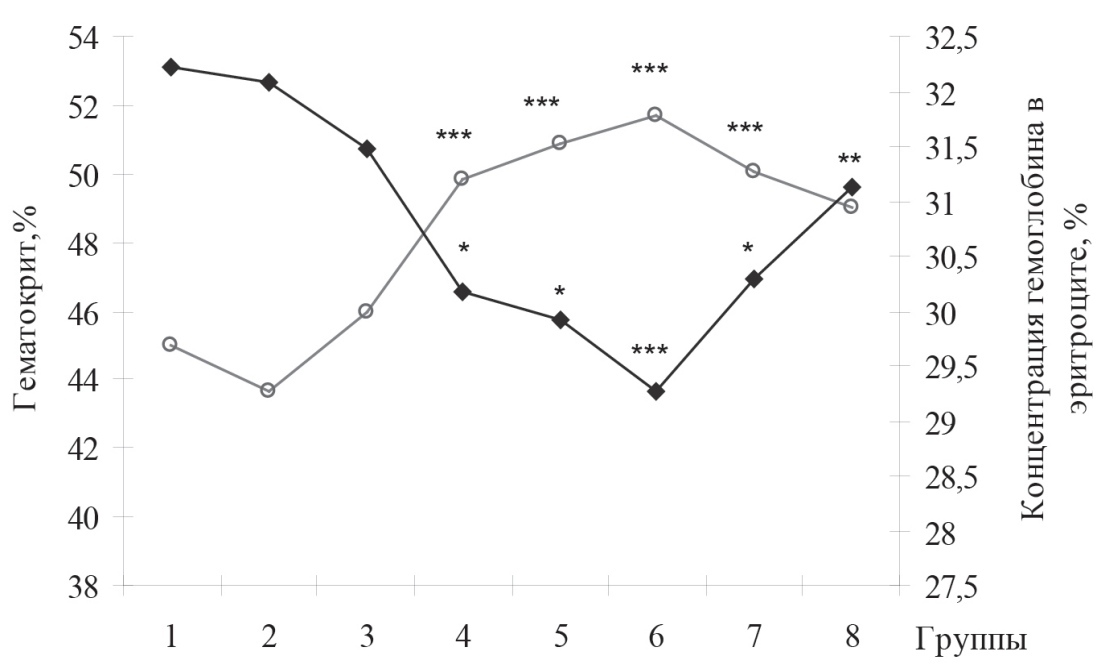

- Гематокрит, $\%$ — Концентрация гемоглобина в эритроците, $\%$

Рис. 2. Изменение величины гематокрита и концентрации гемоглобина в эритроците крыс в условиях физической нагрузки разной интенсивности.

Статистически значимые отличия показателей: при ${ }_{-}^{*} \mathrm{p}<0.05, * *-\mathrm{p}<0.01, * * *$ $\mathrm{p}<0.001$ по отношению к животным первой группы.

По мере увеличения массы груза уменьшается время плавания животных. По сравнению с крысами четвертой группы, плававших в течение 82 мин, время плавания крыс в восьмой группе уменьшилось до 1.3 мин. Считается, что кратковременная физическая нагрузка затрагивает изменения, прежде всего, на уровне мембраны эритроцита [34]. В это же время отмечали однотипность в реактивности исследуемых параметров красной крови животных в условиях нагрузочного плавания. Повышение величины гематокрита, гемоглобина, эритроцитов и увеличение количества ретикулоцитов и их среднего диаметра, содержания гемоглобина, наряду с уменьшением концентрации гемоглобина в эритроците, можно рассматривать как следствие срочной адаптации организма крыс на действие физической нагрузки.

В отличие от животных шестой группы, которые характеризуется наибольшими изменениями параметров красной крови, у крыс седьмой и восьмой групп, отмечали тенденцию к меньшему увеличению количества и среднего диаметра эритроцитов, и меньшему снижению концентрации 
гемоглобина в эритроците на фоне уменьшения времени плавания. Это может свидетельствовать о недостаточности времени у животных для реализации перераспределения резервов функциональных систем.

\section{Выводы}

Таким образом, в зависимости от характера и интенсивности физической нагрузки у крыс проявились разнонаправленные сдвиги в клеточном составе красной крови вследствие адаптивных реакций организма. Тестируемая физическая нагрузка «до отказа» крыс сопровождалась физиологическим ретикулоцитозом, свидетельствующим об активном выходе эритроидных клеток из красного костного мозга и, вероятно, преимущественной устойчивостью крупных эритроцитов, что соответствует правостороннему сдвигу кривой Прайс-Джонса.

Повышение уровня гематокрита, гемоглобина связано с увеличением кислородной емкости крови, а снижение концентрации гемоглобина в эритроците обусловливает, вероятно, более эффективное обеспечение кислородом работающие мышцы животного.

На основании полученных результатов можно заключить, что выполнение физической нагрузки - плавание 3-9 мин с грузом 8\% от массы тела связано с физиологической реакцией эритроцитов раскрывающей адаптационную особенность изменения периферического звена эритрона в условиях мышечной активности.

Работа выполнена по программе Фундаментальных научных исследований РАН на 2013-2020 г2. (№ ГР АААA-A17-117012310153-9).

\section{Сиисок литературы}

1. Mairbäurl H. Red blood cells in sports: effects of exercise and training on oxygen supply by red blood cells // Frontiers in Physiology. 2013. Vol. 4. P. 332.

2. Викулов А.Д., Маргазин В.А., Бойков В.Л. Диаметр эритроцитов как надежный маркер текущего функционального состояния организма и физической работоспособности спортсменов // Лечебная физкультура и спортивная медицина. 2015. №1. С. 10-14.

3. Lombardi G., Colombini A., Lanteri P., Banfi G. Reticulocetes in sports medicine: an update // Adv. Clin. Chem. 2013. № 59, pp. 125-153.

4. Варламова Н.Г., Логинова Т.П., Мартынов Н.А., Черных А.А., Расторгуев И.А., Гарнов И.О., Ларина В.Е., Бойко Е.Р. Кардиореспираторные предикторы завершения теста с максимальной нагрузкой у высококвалифициро- 
ванных лыжников-гонщиков // Спортивная Медицина: наука и практика. 2015. № 2. С. 53-60.

5. Дигурова И.И., Поздняков Н.О. Оценка гемореологических изменений при физической нагрузке разной интенсивности у крыс // Вестник КрасГАУ. 2009. №1. С. 97-99.

6. Карчинская Т.В. Лабораторная гемоцитология: методы исследования и клинико-диагностическое значение изучения эритроцитов. Методические рекомендации. Ставрополь: Изд-во СевКавГТУ, 2007. 62 с.

7. Марышева В.В., Лукк М.В., Юнусов И.А., Шабанов П.Д. Отсроченное действие гидробромида 2-амино-4-ацетилтиазоло [5, 4-b] индола на физическую выносливость у мышей // Эксперим. и клин. фармакол. 2010. Т. 73, №7. C. 19-22.

8. Cluitmans J.C.A., Gevi F., Siciliano A., Matte A., Leal J. K.F., Franceschi L.D., Zolla L., Brock R., Adjobo-Hermans M.J.W., Bosman G.J.G.C.M. Red Blood Cell Homeostasis: Pharmacological Interventions to Explore Biochemical, Morphological and Mechanical Properties // Front. Mol. Biosci. 2016. Vol. 3. P. 10.

9. Хныченко Л.К., Сапронов Н.С. Стресс и его роль в развитии патологических процессов // Обзоры по клинич. фармакол. и лек. терапии. 2003. Т. 2. C. $2-15$.

10. Laughlin M.N., Davis M.J., Secher N.H., van Lieshout J.J., Arce-Esquvel A.A., Simmons G.H., Bender S.B., Padilla J., Bache R.J., Merkus D., Duncker D.J. Peripheral circulation // Compr. Physiol. 2012. № 2, pp. 321-447.

11. Cicha I., Suzuki Y., Tateishi N., Maeda N. Changes of RBC aggregation in oxygenation-deoxygenation: $\mathrm{pH}$ dependency and cell morphology // Am. J. Physiol. Heart Circ. Physiol. 2003. Vol. 284, № 6, pp. 2335-2342.

12. Дроздов Д.Н., Кравцов А.В. Особенности вариаций показателей периферической крови до и после действия физической нагрузки // Специфические и неспецифические механизмы адаптации во время стресса и физической нагрузки: Сб. науч. статей II Республиканской науч.-практ. интернет-конф. с междунар. участием (Республика Беларусь, г. Гомель, 19 декабря 2014 г). Гомель: ГомГМУ, 2014. С. 99-101.

13. Schmidt G., Gross J., Necas E., Neuwirt J. Veranderungen erythrozytar Kriterien des Meerschweinchens bei Hypoxie // Acta boil. Med. Germ. 1977. B. 36. S. 205-211.

14. Крылов В.Н., Дерюгина А.В., Плескова С.Н. Электрофоретическая подвижность и морфометрия эритроцитов крыс при стрессовых воздействиях // Соврем. технол. мед. 2010. № 4. С. 23-26. 
15. Иржак Л.И., Гладилов В.В., Мойсеенко Н.А. Дыхательная функция крови в условиях гипероксии. М.: Медицина, 1985. $176 \mathrm{c}$.

16. Brito A.F., Silva A.S., Souza I.L.L., Pereira J.C., Martins I.R.R., Silva B.A. Intensity of swimming exercise influences tracheal reactivity in rats // J. Smooth. Muscle Res. 2015. Vol. 51, pp. 70-81.

17. Тодоров Й. Клинические лабораторные исследования в педиатрии. София: Медицина, 1968. 1065 с.

18. Гланц С. Медико-биологическая статистика. М.: Практика, 1999. $459 \mathrm{c}$.

19. Абрашова Т.В., Гущин Я.А., Ковалева М.А., Рыбакова А.В., Селезнева А.И., Соколова А.П., Ходько С.В. Справочник. Физиологические, биохимические и биометрические показатели нормы экспериментальных животных / Под редакцией Макарова В.Г., Макаровой М.Н. СПБ.: Изд-во «ЛЕМА», 2013. $116 \mathrm{c}$.

20. Кван О.В., Константинова Ю.А., Алёхина Г.П., Быков А.В. Влияние пробиотических препаратов на гематологические показатели крови лабораторных животных // Вестник ОГУ. 2017. № 6 (206). С. 76-79.

21. Morton D.B., Abbot D., Barclay R., Close B.S., Ewbank R., Gask D., Heath M., Mattis S., Poole T., Seamer J., SoutheeJ., Thompson A., Trussell B., West C., Jenning M. Removal of blood from laboratory mammals and bird // Laboratory animals. 1993. Vol. 27, pp. 1-22.

22. Smith J.A. Exercise, training and red blood cell turnover // Sports Med. 1995. Vol. 19. № 1, pp. 9-31.

23. Кидалов В.Н., Лысак В.Ф. Квантитативная эритрограмма и возможность ее использования в клинике и эксперименте // Лабораторное дело. 1989. № 8. C. 36-40.

24. Garby L., Sjölin S., Vuille J.-C. Disappearance from Plasma and Red-Cell Uptake of Radio-Active Iron Injected Intravenously // Acta Paediatrica (nurturing the child). 1963. Vol. 52, № 6, pp. 537-553.

25. Mercer K.W., Densmore J.J. Hematologic disorders in the athletes // Clin. Sports Med. 2005. Vol. 24, pp. 599-621.

26. Lang F., Busch G.L., Ritter M., Völkl H., Waldegger S., Gulbins E., Haussinger D. Functional significance of cell volume regulatory mechanisms // Physiol Rev. 1998. Vol. 78, № 1, pp. 247-306.

27. Paraiso L.F., Goncalves-E-Oliveira A.F.V., Cunha L.M., Neto O.P.A., Pacheco A.G., Araujo K.B.G., Garrote-Filho V.S., Neto M.B., Penha-Silva N. Effects of acute and chronic exercise on the osmotic stability of erythrocyte membrane of competitive swimmers // PLoS One. 2017. Vol. 12 (2). P. 0171318. 
28. Зайцева М.С, Иванов Д.Г., Александрова Н.В. Работоспособность крыс в тесте «вынужденное плавание с грузом» и причины ее вариабельности // Биомедицина. 2015. № 4. С. 30-42.

29. Рубцова Л.Ю., Потолицына Н.Н., Монгалёв Н.П. Особенности изменения диаметра эритроцитов в крови спортсменов в условиях физической нагрузки // В мире научных открытий. 2017. Т. 9, № 2. С. 121-141.

30. Teległow A., Bilski J., Dabrowski Z., Marchewka A., Jaskiewicz J., Głodzik J., Kępinska M., Lizak D. Changes in morphological and cytological properties of blood during physical exercise in water at $4^{\circ} \mathrm{C}$ and $25^{\circ} \mathrm{C} / /$ Medicina Sportiva. 2011. Vol. 15, № 4, pp. 201-208.

31. Изменение крови во время физической нагрузки. В кн.: Наука о спорте: Спортивная энциклопедия систем жизнеобеспечения /под ред. А.Д.Жукова. М.: Изд-во Магистр-пресс/ЮНЕСКО, 2011. Т. 1. 1000 с.

32. Бойко Е.Р., Бурых Э.А., Потолицына Н.Н., Людинина А.Ю., Вахнина Н.А., Шадрина В.Д., Паршукова О.И., Иржак Л.И., Сороко С.И. Показатели гликемии при выраженной экзогенной острой нормобарической гипоксии у человека в покое // Физиол. человека. 2010. Т. 36, № 3. С. 110-116.

33. Иржак Л.И. Действие растворов солей и глюкозы на сродство гемоглобина к кислороду у крыс // Физиол. журн. СССР. 1988. Т. 74, № 4. С. 564-568.

34. Spodaryk K., Berger L., Hauke S. Influences of physical training on the functional changes of young and old red blood ctlls. Mech Ageing Dev. 1990. 55 (2), pp. 199-206.

\section{References}

1. Mairbäurl H. Red blood cells in sports: effects of exercise and training on oxygen supply by red blood cells. Frontiers in Physiology. 2013, vol. 4, pp. 332.

2. Vikulov A.D., Margazin V.A., Boikov V.L. Diametr eritrocitov kak nadezhnyj marker tekushhego funkcional'nogo sostojanija organizma i fizicheskoj rabotosposobnosti sportsmenov [Erythrocyte diameter as a reliable marker of current functional state of organism and physical performance of athletes]. Lechebnaya fizkul'tura i sportivnaya meditsina. 2015, no 1, pp. 10-14. (in Russian).

3. Lombardi G., Colombini A., Lanteri P., Banfi G. Reticulocetes in sports medicine: an update. Adv. Clin. Chem. 2013, no 59, pp. 125-153.

4. Varlamova N.G., Loginova T.P., Martynov N.A., CHernyh A.A., Rastorguev I.A., Garnov I.O., Larina V.E., Bojko E.R. Kardiorespiratornye prediktory zaversheniya testa $\mathrm{s}$ maksimal'noj nagruzkoj u vysokokvlificirovannyh lyzhnikov-gonshchikov [Cardiorespiratory predictors for maximal load test termination in professional cross-country skiersb]. Sportivnaya Medicina: nau- 
ka i praktika [Sports medicine: research and practice]. 2015, no 2, pp. 53-60. (in Russian).

5. Digurova I.I., Pozdnjakova N.O. Ocenka gemoreologicheskih izmenenij pri fizicheskoj nagruzke raznoj intensivnosti u krys [Evaluation of hemorheological changes under physical exertion of different intensity in rats]. Vestnik Krasnojarskogo gosudarstvennogo agrarnogo universiteta. 2009, no 1, pp. 97-99. (in Russian).

6. Karchinskaya T.V. Laboratornaya gemotsitologiya: metody issledovaniya $i$ kliniko-diagnosticheskoe znachenie izucheniya eritrotsitov. Metodicheskie rekomendatsii [Laboratory gemocitology: research methods and clinical diagnostic value of the study of erythrocytes. Guidelines]. Stavropol': Izdatel'stvo SevKavGTU, 2007. 62 p. (in Russian).

7. Marysheva V.V., Lukk M.V., Yunusov I.A., Shabanov P.D. Otsrochennoe dejstvie gidrobromida 2-amino-4-acetiltiazolo [5, 4-b] indola na fizicheskuju vynoslivost' u myshej [Delayed effect of 2-amino-4-acetylthiazolo[5, 4-b] indole hydrobromide on physical capability in mice]. Eksperimental'naja $i$ klinicheskaja farmakologija [Russian Journal of Experimental and Clinical Pharmacology]. 2010, vol. 73, no 7, pp. 19-22. (in Russian).

8. Cluitmans J.C.A., Gevi F., Sicilianj A., Matte A., Leal J. K.F., Franceschi L.D., Zolla L., Brock R., Adiobo-Hermans M.J.W., Bosman G.J.G.C.M. Red Blood Cell Homeostasist: Pharmacological Interventions to Explore Biochemical, Vorphological and Mechanical Prjperties. Front Mol Biosci., 2016, no 3, p. 10.

9. Khnychenko L.K., Sapronov N.S. Stress i ego rol' v razvitii patologicheskih processov [Stress and its role in the development of pathological processes]. Obzory po klinicheskoi farmakologii i lekarstvennoi terapii. [Surveys of clinical pharmacology and drug therapy]. 2003, vol. 2, no 3, pp. 2-15. (in Russian).

10. Laughlin M.N., Davis M.J., Secher N.H., van Lieshout J.J., Arce-Esquvel A.A., Simmons G.H., Bender S.B., Padilla J., Bache R.J., Merkus D., Duncker D.J. Peripheral circulation. Compr. Physiol., 2012, no 2, pp. 321-447.

11. Cicha I., Suzuki Y., Tateishi N., Maeda N. Changes of RBC aggregation in oxygenation-deoxygenation: $\mathrm{pH}$ dependency and cell morphology. Am. J. Physiol. Heart Circ. Physiol., 2003, vol. 284, no 6, pp. 2335-2342.

12. Drozdov D.N., Kravcov A.V. Osobennosti variacij pokazatelej perifericheskoj krovi do i posle dejstviya fizicheskoj nagruzki. Specificheskie i nespecificheskie mekhanizmy adaptacii vo vremya stressa i fizicheskoj nagruzki: Sb. nauch. statej II Respublikanskoj nauch.-prakt. internet-konf. s mezhdunar. uchastiem (Respublika Belarus', g. Gomel', 19 dekabrya 2014 g). Gomel', 2014, pp. 99-101. 
13. Schmidt G., Gross J., Necas E., Neuwirt J. Veranderungen erythrozytar Kriterien des Meerschweinchens bei Hypoxie. Acta boil. Med. Germ., 1977, b. 36, ss. 205-211.

14. Krylov V.N., Deryugina A.V., Pleskova S.N. Elektroforeticheskaja podvizhnost' i morfometrija eritrocitov krys pri stressovyh vozdejstvijah [Electrophoretic mobility and morphometry of the rat erythrocytes at the stress effects]. Sovremennye tehnologii v medicine, 2010, no 4, pp. 23-26. (in Russian).

15. Irzhak L.I., Gladilov V.V., Mojseenko N.A. Dyhatel'naya funkciya krovi v usloviyah giperoksii. Moscow, Medicina, 1985, 176 s. (in Russian).

16. Brito A.F., Silva A.S., Souza I.L.L., Pereira J.C., Martins I.R.R., Silva B.A. Intensity of swimming exercise influences tracheal reactivity in rats. J. Smooth Muscle Res., 2015, vol. 51, pp. 70-81.

17. Todorov I. Klinicheskie laboratornye issledovaniia v pediatrii [Clinical laboratory studies in pediatric]. Sofiia, Meditsina. 1968. 1065 p. (in Russian).

18. Glanc S. Mediko-biologicheskaya statistika. Moscow, Praktika, 1999, 459 s. (in Russian).

19. Abrashova T.V., Gushhin Ja.A., Kovaleva M.A., Rybakova A.V., Selezneva A.I., Sokolova A.P., Hod'ko S.V. Spravochnik. Fiziologicheskie, biohimicheskie i biometricheskie pokazateli normy eksperimental'nyh zhivotnyh / Ed. By. Makarova V.G., Makarovoj M.N. Saint- Petersburg, Izdatel'stvo «LEMA», 2013, 116 p. (in Russian).

20. Kvan O.V., Konstantinova Yu.A., Alyokhina G.P., Bykov A.V. Vlijanie probioticheskih preparatov na gematologicheskie pokazateli krovi laboratornyh zhivotnyh [Influence of probiotic preparations on blood hematologic parameters of laboratory animals]. Vestnik Orenburgskogo Gosudarstvennogo universiteta, 2017, no 6 (206), pp. 76-79. (in Russian).

21. Morton D.B., Abbot D., Barclay R., Close B.S., Ewbank R., Gask D., Heath M., Mattis S., Poole T., Seamer J., SoutheeJ., Thompson A., Trussell B., West C., Jenning M. Removal of blood from laboratory mammals and bird. Laboratory animals, 1993, vol. 27, pp. 1-22.

22. Smith J.A. Exercise, training and red blood cell turnover. Sports Med. 1995. Vol. 19. № 1, pp. 9-31.

23. Kidalov V.N., Lysak V.F. Kvantitativnaja eritrogramma i vozmozhnost' ee ispol'zovanija v klinike i eksperimente. [Quantitative erythrograms and the possibility of its use in clinical and experimental]. Laboratornoe delo, 1989, no 8, pp. 36-40. (in Russian).

24. Garby L., Sjölin S., Vuille J.-C. Disappearance from Plasma and Red-Cell Uptake of Radio-Active Iron Injected Intravenously. Acta Paediatrica (nurturing the child), 1963, vol. 52, no 6, pp. 537-553. 
25. Mercer K.W., Densmore J.J. Hematologic disorders in the athletes. Clin. Sports Med., 2005, vol. 24, pp. 599-621.

26. Lang F., Busch G.L., Ritter M., Völkl H., Waldegger S., Gulbins E., Haussinger D. Functional significance of cell volume regulatory mechanisms. Physiol Rev., 1998, vol. 78, no 1, pp. 247-306.

27. Paraiso L.F., Goncalves-E-Oliveira A.F.V., Cunha L.M., Neto O.P.A., Pacheco A.G., Araujo K.B.G., Garrote-Filho V.S., Neto M.B., Penha-Silva N. Effects of acute and chronic exercise on the osmotic stability of erythrocyte membrane of competitive swimmers. PLoS One., 2017, vol. 12 (2). P. 0171318.

28. Zaytseva M.S., Ivanov D.G., Alexandrova N.V. Pabotosposobnost' krys v teste «vynuzhdennoe plavanie s gruzom» i prichiny ee variabel'nosti [The rat work capacity in forced swimming test with load and causes it variability]. Biomedicina, 2015, no 4, pp. 30-42. (in Russian).

29. Rubtsova L.Yu., Potolitsyna N.N., Mongalev N.P. Osobennosti izmenenija diametra eritrocitov v krovi sportsmenov v uslovijah fizicheskoj nagruzki [Value change diameter red blood cells athletes in the physical load]. V mire nauchnyh otkrytij [In the World of Scientific Discoveries], 2017, no 2, pp. 121-141. (in Russian).

30. Teległow A., Bilski J., Dabrowski Z., Marchewka A., Jaskiewicz J., Głodzik J., Kępinska M., Lizak D. Changes in morphological and cytological properties of blood during physical exercise in water at $4^{\circ} \mathrm{C}$ and $25^{\circ}$ C. Medicina Sportiva, 2011, vol. 15, no 4, pp. 201-208.

31. Izmenenie krovi vo vremja fizicheskoj nagruzki. Nauka o sporte: enciklopedija sistem zhizneobespechenija [Change in blood during exercise. In the book: The Science of Sport: Sports Encyclopedia of Life Support Systems] / Ed. by. A.D. Zhukov. Moscow, 2011, tome 1, 1000 s. (in Russian).

32. Bojko E.R., Burykh E.A., Potolitsyna N.N., Ludinina A.Yu., Vahnina N.A., Shadrina V. D, Parshukova O.I., Irzhak L.I., Soroko S.I. Pokazateli glikemii pri vyrazhennoj ekzogennoj ostroj normobaricheskoj gipoksii u cheloveka $\mathrm{v}$ pokoe [Serum Glucose Level in Acute Severe Hypoxia in Human at Rest]. Fiziologija cheloveka [Human Physiology], 2010, vol. 36, no 3, pp. 110-116. (in Russian).

33. Irzhak L.I. Dejstvie rastvorov solej i gljukozy na srodstvo gemoglobina k kislorodu u krys [Effect of solutions of salts and glucose on the affinity of hemoglobin for oxygen in rats]. Fiziologicheskij zhurnal SSSR, 1988, vol. 74, no 4, pp. 564-568. (in Russian).

34. Spodaryk K., Berger L., Hauke S. Influences of physical training on the functional changes of young and old red blood ctlls. Mech Ageing Dev., 1990, vol. 55, no 2, pp. 199-206. 


\section{ДАННЫЕ ОБ АВТОРАХ}

Монгалёв Николай Петрович, к.б.н., старший научный сотрудник Отдела экологической и медицинской физиологии Федеральное государственное бюджетное учреждение науки Институт физиологии Коми научного ичентра Уральского отделения Российской академии наук

ул. Первомайская, 50, г. Сыктывкар, 167982, Республика Коми, Российская Федерация mongalev@physiol.komisc.ru

Рубцова Лидия Юрьевна, младший научный сотрудник Отдела экологической и медицинской физиологии

Федеральное государственное бюджетное учреждение науки Институт физиологии Коми научного иентра Уральского отделения Российской академии наук

ул. Первомайская, 50, г. Сыктывкар, 167982, Республика Коми, Российская Федераиия

lidiyarubcova@mail.ru

Шадрина Вера Дмитриевна, научный сотрудник Отдела экологической и медицинской физиологии

Федеральное государственное бюджетное учреждение науки Институт физиологии Коми научного иеентра Уральского отделения Российской академии наук

ул. Первомайская, 50, г. Сыктывкар, 167982, Республика Коми, Российская Федераиия Vera.shadrina56@mail.ru

Черных Алексей Анатольевич, младший научный сотрудник отдела экологической и медицинской физиологии Федеральное государственное бюджетное учреждение науки Институт физиологии Коми научного центта Уральского отделения Российской академии наук

ул. Первомайская, 50, г. Сыктывкар, 167982, Республика Коми, Российская Федерачия death.elephant@gmail.com

Вахнина Надежда Алексеевна, старший научный сотрудник отдела экологической и медицинской физиологии 
Федеральное государственное бюджетное учреждение науки Институт физиологии Коми научного иеентра Уральского отделения Российской академии наук

ул. Первомайская, 50, г. Сыктывкар, 167982, Республика Коми, Российская Федерация vakhnina80@mail.ru

Макарова Ирина Александровна, ст. лаборант, отдела экологической и медицинской физиологии Федеральное государственное бюджетное учреждение науки Институт физиологии Коми научного центра Уральского отделения Российской академии наук

ул. Первомайская, 50, г. Сыктывкар, 167982, Республика Коми, Российская Федерачия makarova_irina0307@mail.ru

Романова Анастасия Михайловна, аспирант отдела экологической и медицинской физиологии Федеральное государственное бюджетное учреждение науки Институт физиологии Коми научного центра Уральского отделения Российской академии наук

ул. Первомайская, 50, г. Сыктывкар, 167982, Республика Коми, Российская Федерачия anastasiapomanova2509@yandex.ru

Алисултанова Надежда Жафаровна, младший научный сотрудник отдела экологической и медицинской физиологии Федеральное государственное бюджетное учреждение науки Институт физиологии Коми научного центра Уральского отделения Российской академии наук

ул. Первомайская, 50, г. Сыктывкар, 167982, Республика Коми, Российская Федерация alisultanova.nadezhda@mail.ru

Василенко Татьяна Федоровна, вед.н.с. отдела экологической и медицинской физиологии Федеральное государственное бюджетное учреждение науки Институт физиологии Коми научного иентта Уральского отделения Российской академии наук ул. Первомайская, 50, г. Сыктывкар, 167982, Республика Коми, Российская Федерачия 
vasilenko@physiol.komisc.ru

Бойко Евгений Рафаилович, директор Института физиологии Коми научного центра Уральского отделения РАН, заведующий кафедрой биохимии и экстремальной медицины медицинского института Сыктывкарского государственного университета имени Питирима Сорокина Федеральное государственное бюджетное учреждение науки Институт физиологии Коми научного иентра Уральского отделения Российской академии наук

ул. Первомайская, 50, г. Сыктывкар, 167982, Республика Коми, Российская Федерачия erbojko@physiol.komisc.ru

\section{DATA ABOUT THE AUTHORS}

Mongalev Nikolay Petrovich, Cand. of Biol. Sc., Senior Researcher Institute of Physiology, Komi Science Centre, Urals Branch of Russian Academy of Science 50, Pervomaysksya Str., Syktyvkar, 167982, Russian Federation mongalev@physiol.komisc.ru SPIN-code: 6768-5599 ORCID: 0000-0002-2817-5780 ResearcherID: P-9671-2016

Rubtsova Lidiya Yurevna, Research Assistant Institute of Physiology, Komi Science Centre, Urals Branch of Russian Academy of Science 50, Pervomaysksya Str., Syktyvkar, 167982, Russian Federation lidiyarubcova@mail.ru SPIN-code: 3083-6642 ORCID: 0000-0003-3262-7337 ResearcherID: C-6803-2017

Shadrina Vera Dmitrievna, Cand. of Biol. Sc., Senior Researcher Institute of Physiology, Komi Science Centre, Urals Branch of Russian Academy of Science 50, Pervomaysksya Str., Syktyvkar, 167982, Russian Federation Vera.shadrina56@mail.ru

Chernykh Aleksey Anatol'evich, Research Assistant Institute of Physiology, Komi Science Centre, Urals Branch of Russian Academy of Science 
50, Pervomaysksya Str., Syktyvkar, 167982, Russian Federation death.elephant@gmail.com

Vahnina Nadezhda Alekseevna, Cand. of Biol. Sc., Senior Researcher Institute of Physiology, Komi Science Centre, Urals Branch of Russian Academy of Science 50, Pervomaysksya Str., Syktyvkar, 167982, Russian Federation vakhnina80@mail.ru

Makarova Irina Aleksandrovna, Master

Institute of Physiology, Komi Science Centre, Urals Branch of Russian Academy of Science 50, Pervomaysksya Str., Syktyvkar, 167982, Russian Federation makarova_irina0307@mail.ru

Romanova Anastasiya Mikhaylovna, Postgraduate Student

Institute of Physiology, Komi Science Centre, Urals Branch of Russian Academy of Science

50, Pervomaysksya Str., Syktyvkar, 167982, Russian Federation anastasiapomanova2509@yandex.ru

Alisultanova Nadezhda Zhafarovna, Cand. of Biol. Sc., Research Assistant Institute of Physiology, Komi Science Centre, Urals Branch of Russian Academy of Science 50, Pervomaysksya Str., Syktyvkar, 167982, Russian Federation alisultanova.nadezhda@mail.ru

Vasilenko Tatyana Fedorovna, Dr. of Biol. Sc., Senior Researcher Institute of Physiology, Komi Science Centre, Urals Branch of Russian Academy of Science 50, Pervomaysksya Str., Syktyvkar, 167982, Russian Federation vasilenko@physiol.komisc.ru

Boyko Evgeniy Rafailovich, MD, Professor

Institute of Physiology, Komi Science Centre, Urals Branch of Russian Academy of Science 50, Pervomaysksya Str., Syktyvkar, 167982, Russian Federation erbojko@physiol.komisc.ru 